\title{
Vnímání chemie žáky druhého stupně základních škol
}

\author{
Milan Kubiatko ${ }^{1}$, Kateřina Švandová ${ }^{1}$, Jiř́ Šibor ${ }^{2}$, Jiř́ Š ̌́koda ${ }^{3}$ \\ ${ }^{1}$ Masarykova univerzita, Pedagogická fakulta, Institut výzkumu školního vzdělávání \\ ${ }^{2}$ Masarykova univerzita, Pedagogická fakulta, Katedra chemie \\ ${ }^{3}$ Univerzita Jana Evangelisty Purkyně, Pedagogická fakulta, Katedra pedagogiky
}

Redakci zasláno 13. 6. 2011 / Do tisku přijato 8. 3. 2012

\begin{abstract}
Abstrakt: Výzkumných prací týkajících se zkoumání postojů žáků k chemii není mnoho. Ve většině př́ípadů se jedná o výzkumné práce zaměřené na vliv genderu na utváření postojů $\mathrm{k}$ uvedenému předmětu. $\mathrm{V}$ předkládané studii byl kromě vlivu genderu zjištován i vliv ročníku, oblíbeného předmětu a celkový postoj žáků $\mathrm{k}$ chemii. Výzkumný vzorek byl tvořen 379 žáky druhého stupně z osmi českých základních škol. Poměr děvčat a chlapců byl přibližně vyrovnaný. Více žáků bylo $\mathrm{z}$ osmého ročníku $(n=236)$ a žáků s oblíbeným prrírodovědným předmětem bylo 102 . Jako výzkumný nástroj byl použit dotazník obsahující 25 škálovaných položek Likertova typu. Použitím faktorové analýzy byly položky rozděleny do 4 dimenzí: Zájem o chemii, Význam chemie, Budoucí život a chemie, Chemické experimenty. Na zjištění rozdílů u jednotlivých proměnných byl použit t-test pro nezávislé výběry. Významný rozdíl byl zjištěn pouze u proměnné oblíbený předmět ve prospěch žáků $s$ chemií jakožto oblíbeným předmětem. Děvčata dosahovala pozitivnějšího postoje $\mathrm{k}$ chemii než chlapci. Žáci obou ročníků dosáhli přibližně vyrovnaného skóre. Na závěr jsou navrženy možnosti dalšího směřování výzkumu v této oblasti.
\end{abstract}

Klíčová slova: postoje k chemii, škálovaný dotazník, žáci II. stupně českých základních škol

\section{1 Úvod}

Zkoumání postojů $\mathrm{v}$ oblasti př́rodovědných předmětů patří mezi důležité výzkumné oblasti, zejména $\mathrm{z}$ důvodu vztahu mezi postoji žáků k předmětu a jejich úspěšností v daném předmětu. Uvedené tvrzení platí i pro chemii, která patří do skupiny př́rodovědných předmětů. Vztah mezi postoji a úspěšností je potvrzen výzkumnými šetřeními - např́́klad Weinburgh (1995) a Salta a Tzougraki (2004) uvádí hodnotu korelace mezi postoji $\mathrm{k}$ přírodovědným předmětům a úspěšností u žáků základních škol vyšší než 0,50 . Kromě pozitivního vlivu mezi postoji a úspěšností, jedním z dalších 
důvodů, proč by měly být rozvíjeny pozitivní postoje k chemii, je uplatnění žáků $\mathrm{v}$ oblasti chemie $\mathrm{v}$ budoucím životě. Podobného názoru jsou také Glasman a Albarracín (2006) a Kelly (1988), kteří poukazují na to, že postoje jsou dobrým prediktorem pro výběr budoucího povolání.

Studie nastiňuje vnímání chemie žáky druhého stupně základních škol v České republice. V kapitole „Teoretická východiska“ je ve stručné podobě načrtnuto chápání postojů $\mathrm{v}$ obecné rovině a taktéž současný stav řešené problematiky týkající se zkoumání postojů k chemii. Metodická kapitola představuje výzkumný vzorek, nástroj, jeho administraci a analýzu získaných dat. Ve výsledkové kapitole jsou nastíněna základní zjištění týkající se toho, jak žáci základních škol vnímají chemii, a dále jsou zde porovnány rozdíly mezi skupinami jednotlivých proměnných (gender, třída, oblíbený předmět). V kapitole Diskuse jsou uvedeny odpovědi na výzkumné otázky a závěrečná kapitola sumarizuje hlavní výsledky a navrhuje další směrování výzkumu $\mathrm{v}$ této oblasti.

\section{Teoretická východiska: základní pojmy a stav poznání}

Základem každé publikované definice týkající se postojů je predispozice subjektu zaujmout negativní nebo pozitivní stanovisko k hodnocenému objektu (Oskamp \& Schultz, 2005, s. 8). Morrell a Ledermann (1998), vycházející z obecné definice, charakterizují postoje $\mathrm{k}$ př́rodovědným předmětům jako pozitivní nebo negativní pocity k dané skupině předmětů. Danou definici je možné vztáhnout i na chemii jako jeden ze skupiny př́rodovědných předmětů. Objektem hodnocení může být cokoliv - může to být chemie jako celek, případně učitelé chemie nebo samotné hodiny výuky chemie či další aspekty související s chemií.

Co se týče současného stavu řešené problematiky je patrné, že prací zaobírajících se zkoumáním postojů žáků základních škol k chemii je relativně malé množství. $\mathrm{Z}$ českého a slovenského prostředí je to studie od Veselského a Hausnerové (2010), kteří zkoumali míru zájmu žáků o př́rodovědné předměty a hodnotili relativní pozici chemie $\mathrm{v}$ rámci přírodovědných předmětů. Výzkumný vzorek tvořili žáci devátých ročníků základních škol a zájem byl zjištován pomocí škálovaného dotazníku se 4-stupňovými položkami. Chemie byla hodnocena jako nejméně zajímavá v porovnání s ostatními př́rodovědnými předměty. Autoři kromě celkového zájmu zjištovali také rozdíl mezi chlapci a dívkami, kdy chlapci projevili vyšší 
zájem o chemii. Autoři Veselský a Hrubišková (2009) publikovali obdobnou studii, pouze s tím rozdílem, že jednotkou výzkumu byli studenti prvního ročníku gymnázia a výzkumný nástroj obsahoval 5-stupňovou škálu. Chemie byla hodnocena jako $\mathrm{v}$ pořadí druhý nejzajímavější předmět $\mathrm{v}$ porovnání s ostatními přírodovědnými předměty, přesto skóre indikovalo relativní nezájem o předmět. Při porovnání chlapců a dívek byl zjištěn opačný výsledek než v předešlé studii. Dívky prokázaly vyšší zájem o chemii než chlapci. V další studii Pavelková, Škaloudová a Hrabal (2010) zkoumali mimo jiné oblibu, obtížnost a význam jednotlivých předmětů u žáků druhého stupně základních škol. Jako výzkumný nástroj sloužil autorům škálovaný dotazník s 5-stupňovými položkami. Chemie byla dle autorů hodnocena žáky spíše jako neoblíbený, obtížný, málo významný předmět. Rozdíly mezi chlapci a dívkami nebyly potvrzeny $\mathrm{v}$ žádné $\mathrm{z}$ výše uvedených charakteristik.

Mezi zahraniční studie zabývající se zkoumáním postojů žáků k chemii patří příspěvek Dhindsa a Chung (1999), kteří se zaměřili na vnímání chemie žáky ve čtyřech dimenzích (radost, motivace, strach a důležitost chemie). Postoje k chemii byly měřeny prostřednictvím škálovaných položek. Autoři zjistili pozitivnější vnímaní chemie dívkami nežli chlapci. Menis (1983) měřil úroveň postojů u žáků izraelských základních škol pomocí dotazníku se škálovanými položkami. Postoje byly měřeny nejen v obecné rovině, ale též v dalších čtyřech dimenzích: zájem o chemii, využití chemie, důležitost chemie a radost z chemie. Autor zjistil pozitivnější vnímání chemie chlapci než dívkami. Dále se kromě zkoumání vlivu pohlaví zaměřil i na zkoumání vlivu věku na postoje $\mathrm{k}$ chemii a zjistil, že zájem o chemii je $\mathrm{v}$ pozitivní korelaci s věkem respondentů. Harvey a Stables (1986) zkoumali u osmi až desetitiletých žáků z Velké Británie nejen postoje k chemii, ale také postoje $\mathrm{k}$ fyzice a prŕrodopisu. Zjištěné výsledky byly podobné jako v předchozí studii. Velmi zajímavou genderovou komparaci postojů žáků k prrírodním vědám a výuce př́rodovědných předmětů přináší i projekt ROSE (The Relevance of Science Education; Sjøberg \& Schreiner, 2010) uskutečňovaný na vzorku patnáctiletých žáků ve 37 zemích celého světa. Výsledky potvrzují poměrně značné rozdíly $\mathrm{v}$ přístupu chlapců a děvčat $\mathrm{k}$ přírodním vědám.

Součástí prezentovaného výzkumu je i zkoumání vlivu oblíbeného předmětu na postoje $\mathrm{k}$ chemii. Vliv oblíbeného předmětu na úroveň postojů $\mathrm{k}$ chemii jako takový v dostupných studiích nebyl detekován. Zkoumání této proměnné se nejvíce přiblížila práce Salta a Tzougraki (2004), kteří zjištovali postoj řeckých středoškolských studentů $\mathrm{k}$ výše zmíněným čtyřem dimenzím 
s ohledem na jejich zaměření studia. Studenti, kteří ke svému dalšímu studiu budou potřebovat chemii, dosahovali ve všech dimenzích významné pozitivnější skóre $\mathrm{v}$ porovnání $\mathrm{s}$ ostatními dvěma skupinami (studenti zaměření na studium humanitních a technických předmětů).

\section{Důvod výzkumného šetření}

Jak je nastíněno výše, dostupných výzkumných prací týkajících se zjištování postojů žáků základních škol k chemii není mnoho. Proto je jedním z důvodů výzkumného šetření rozširríit výzkumnou oblast týkající se zkoumání postojů českých žáků druhého stupně základních škol k chemii. Kromě zjištění, jaká je úroveň postojů českých žáků k chemii, byl zjištován také vliv genderu, ročníku a oblíbeného předmětu na postoje žáků k chemii.

Byly stanoveny následující výzkumné otázky:

1. Jaký je vliv genderu na úroveň postojů žáků k chemii?

2. Existuje vztah mezi ročníky, které žáci navštěvují, a úrovní postojů $\mathrm{k}$ chemii?

3. Existuje vztah mezi oblíbeným předmětem žáků a postoji $\mathrm{k}$ chemii?

Na základě výzkumných otázek byly stanoveny následující hypotézy:

H1: Chlapci mají pozitivnější postoje k chemii v porovnání s dívkami.

H2: Žáci devátých ročníků mají pozitivnější vztah k chemii než žáci osmých ročníků.

H3: Žáci s oblíbeným př́rodovědným předmětem mají pozitivnější postoje $\mathrm{k}$ chemii než žáci s jiným oblíbeným předmětem než př́ŕrodovědným.

\section{$4 \quad$ Metodika}

\subsection{Výzkumný vzorek}

Výzkumný vzorek byl tvořen 379 žáky druhého stupně z osmi státních českých základních škol získaných dostupným výběrem. Základní školy byly městského typu s přibližným počtem žáků ve třídě $(n=20)$. Poměr chlapců a děvčat byl přibližně vyrovnaný. Děvčata tvořila 55,15 \% výzkumného vzorku. Do výzkumného šetření byli zahrnuti žáci osmých a devátých ročníků 
základních škol (z důvodu, že výuka chemie probíhá pouze v těchto dvou ročnících). Počet žáků osmého ročníku byl vyšší $(n=236)$, zbytek tvořili žáci devátého ročníku. Průměrný věk respondentů byl 14,06 $(\mathrm{SD}=0,76)$ a pohyboval se v rozmezí od 13 do 16 let. Dle oblíbeného předmětu byli žáci rozděleni do dvou skupin: první skupinu tvořili žáci, kteří označili jako oblíbený předmět jeden z př́rodovědných $(n=100)$, druhou skupinu tvořili žáci s jiným oblíbeným předmětem než přírodovědným $(n=279)$. Mezi přírodovědné předměty byly zařazeny prrírodopis, chemie, fyzika a zeměpis.

\subsection{Výzkumný nástroj}

Výzkumným nástrojem byl dotazník s 5-stupňovými škálovanými položkami Likertova typu. Podkladem pro tvorbu výzkumného nástroje byl dotazník použitý na měření postojů žáků k přírodopisu (Prokop \& Komorníková, 2007). Položky byly přeformulovány tak, že pojem př́rodopis byl nahrazen pojmem chemie. Původní dotazník byl originálně vytvořen ve slovenštině, z důvodu použití $\mathrm{v}$ českých podmínkách byl jeho překlad zabezpečen za asistence lingvisty. Dotazník byl rozdělen na dvě základní části: první část tvořily demografické položky (gender, věk, třída - ročník a oblíbený předmět), druhá část byla tvořena 25 postojovými položkami. Použitím faktorové analýzy (viz podkapitola 4.4) byly položky rozděleny do čtyř skupin - Zájem o chemii, Význam chemie, Budoucí život a chemie, Chemické experimenty (tabulka 1). Položky $\mathrm{v}$ dotazníku byly uvedeny jak $\mathrm{v}$ pozitivním, tak $\mathrm{v}$ negativním významu. Počet pozitivních položek byl 15, které byly pro účely statistického zpracování převedeny do číselné podoby následovně: zcela nesouhlasím - 1; spíše nesouhlasím - 2; ani souhlasím, ani nesouhlasím - 3; spíše souhlasím 4; zcela souhlasím - 5. Negativní položky byly skórovány opačně. Celkové skóre ukazovalo na postoje žáků k chemii. Nízké skóre reflektovalo relativně negativní postoj žáků k chemii, naopak vysoké skóre relativně pozitivní vztah žáků $\mathrm{k}$ danému předmětu. Konstruktová validita byla zabezpečena dvěma způsoby. První způsob spočíval v hodnocení výzkumného nástroje experty, kterými byli $\mathrm{v}$ našem případě odborníci na tvorbu dotazníků a učitelé chemie na základních školách. Hodnotitelé byli požádáni o vyjádření se $\mathrm{k}$ jednotlivým položkám, jejich srozumitelnosti a náročnosti pro žáky druhého stupně základních škol. Na základě jejich návrhů byly provedeny drobné změny v položkách, a to tak, aby se jejich význam neodlišoval od původního dotazníku. Druhým způsobem určení konstruktové validity byla realizace explorativní faktorové analýzy (viz podkapitola 4.4). 


\subsection{Administrace výzkumného nástroje}

Výzkumný nástroj byl administrován na 8 základních školách. Školy byly městského typu, kde počet žáků v jedné třídě nepřesáhl 25 žáků. Ve všech př́padech byly administrátory učitelé, kteří byli poučeni, jak pracovat s výzkumným nástrojem, aby mohli zodpovědět případné otázky žáků. Žáci byli obeznámeni s anonymitou výzkumného šetření a také s tím, že získané údaje budou použity pouze pro výzkumné účely. Respondentům nebyl zadán časový limit pro vyplnění, doba vypracování nepřesáhla 20 minut. Všechny dotazníky byly vyplněny tak, aby je bylo možné zahrnout do analýz.

\subsection{Analýza získaných dat}

Získané údaje byly po jejich převedení do číselné podoby podrobeny explorativní faktorové analýze s Varimax rotací. Před samotným použitím faktorové analýzy bylo nutné provést testy, které dovolují její použití. Jako první byla stanovena normalita pomocí Kolmogorova-Smirnovova testu. Uvedený test byl zvolen proto, že výzkumný vzorek byl tvořen více než 50 respondenty. Hodnota testu $(\mathrm{d}=0,06 ; \mathrm{p}>0,20)$ potvrdila normální rozložení dat. Dalšími testy byly Kaiser-Mayer-Olkinův (KMO) test a Bartlettův test sféricity. Výsledky obou testů dovolily použít faktorovou analýzu. Hodnota KMO testu byla 0,88 a hodnota Bartlettova testu sféricity byla $\chi^{2}=4224,21(p<0,001)$. Jak již bylo zmíněno výše, položky byly rozděleny do 4 dimenzí: 1 . Zájem o chemii (8 položek); 2 . Význam chemie (5 položek); 3. Budoucí život a chemie ( 3 položky); 4 . Chemické experimenty ( 3 položky). Tyto dimenze vysvětlovaly $42,16 \%$ celkového rozptylu, přičemž nejvíce bylo vysvětleno první dimenzí (24,20\%). Kritickou hodnotu pro zařazení položky do dimenze byla hodnota faktorového skóre 0,40 . Z dalších analýz bylo eliminováno 5 položek, u nichž byla hodnota faktorového skóre nižší než 0,40 . Výsledky faktorové analýzy jsou uvedeny v tabulce 1.

Reliabilita výzkumného nástroje byla stanovena pomocí Cronbachovo alfa koeficientu, jehož hodnota $(\alpha=0,87)$ indikuje vysokou spolehlivost výzkumného nástroje. Při statistickém zpracování byly demografické položky (gender, ročník a oblíbený předmět) brány jako nezávislé proměnné. Skóre z postojové části bylo bráno jako závislá proměnná. Na určování rozdílů mezi skupinami jednotlivých nezávislých proměnných byl použit příslušný typ Studentova t-testu pro nezávislé výběry dat. U proměnných ročník a oblíbený předmět byla použita varianta daného testu pro nestejné výběry, protože rozdíl mezi nimi byl velký (více než 1,5x). 


\section{Tabulka 1}

\section{Výsledky faktorové analýzy}

\section{$\begin{array}{llll}\text { I } & \text { II } & \text { III } & \text { IV }\end{array}$}

\section{Zájem o chemii}

1. Chemii mám raději, než ostatní předměty.

$\mathbf{0 , 6 6} \quad 0,11 \quad 0,00 \quad 0,31$

4. Hodiny chemie jsou pro mě náročné.

$\mathbf{0 , 4 4} \quad 0,01 \quad 0,15 \quad 0,15$

6. Hodiny chemie by chtěl/a mít častěji.

$\mathbf{0 , 6 4} \quad 0,05 \quad 0,12 \quad 0,31$

8. V hodinách chemie se nudím.

$\mathbf{0 , 7 5} \quad 0,16 \quad 0,10 \quad 0,12$

10. Výklad učitele v hodinách chemie je pro mě zajímavý.

$\mathbf{0 , 5 6} \quad 0,17 \quad 0,10 \quad 0,35$

15. Domnívám se, že ve srovnání s ostatními vyučovacími předměty není chemie důležitá.

$\mathbf{0 , 5 3} \quad 0,28 \quad 0,29 \quad 0,14$

20. Nemám rád/a hodiny chemie.

$\mathbf{0 , 7 6} \quad 0,07 \quad 0,18 \quad 0,20$

21. Nemám rád/a mého učitele/učitelku chemie.

$\mathbf{0 , 5 6} \quad 0,09 \quad-0,08 \quad-0,16$

\section{Význam chemie}

3. Chemie a př́roda jsou mně cizí.

$\begin{array}{llll}0,29 & \mathbf{0 , 4 2} & 0,29 & -0,06\end{array}$

9. Pokrok v oblasti chemie zkvalitňuje naše životy.

$\begin{array}{llll}0,08 & \mathbf{0 , 7 4} & -0,03 & 0,10\end{array}$

11. Chemické poznatky mohou pomoci při řešení problémů souvisejících s přírodním prostředím.

$0,11 \quad \mathbf{0 , 6 5} \quad 0,06 \quad 0,32$

17. Př́roda je důležitou součástí lidského života. $\quad \begin{array}{rrrr}0,14 & \mathbf{0 , 6 5} & -0,10 & 0,04\end{array}$

$\begin{array}{lllll}\text { 23. Procesy probíhající v př́rodě považuji za zajímavé. } & 0,13 & \mathbf{0 , 5 7} & 0,15 & 0,16\end{array}$

\section{Budoucí život a chemie}

13. Moje budoucí kariéra je nezávislá od vědomostí $\mathrm{z}$ chemie.

$0,16 \quad-0,20 \quad \mathbf{0 , 7 3}-0,05$

18. Po dokončení studia bych chtěl/a pracovat v oblasti přírodních věd.

$0,08 \quad 0,26 \quad \mathbf{0 , 5 8} \quad 0,06$

19. Poznatky z chemie nejsou pro každodenní život potřebné.

$0,15 \quad 0,02 \quad \mathbf{0 , 5 6} \quad 0,21$

\section{Chemické experimenty}

5. Při chemických laboratorních cvičeních dochází $\mathrm{k}$ rozvoji mých vědomostí a dovedností.

$0,31 \quad 0,30 \quad-0,02 \quad \mathbf{0 , 5 3}$

14. Chemické pomůcky využívané v hodinách chemie mě zajímají.

$0,19 \quad 0,16 \quad 0,16 \quad \mathbf{0 , 6 5}$

22. V hodinách chemie používáme hodně chemických pomůcek.

$\begin{array}{llll}0,09 & 0,07 & 0,03 & \mathbf{0 , 7 0}\end{array}$

24. Chemické experimenty jsou velmi zajímavé.

vlastní číslo

$\begin{array}{rrrr}0,32 & 0,38 & -0,15 & \mathbf{0 , 4 5} \\ \mathbf{6 , 0 5} & \mathbf{2 , 2 1} & \mathbf{1 , 3 3} & \mathbf{1 , 0 4}\end{array}$

$\%$ rozptylu

$\begin{array}{llll}24,20 & 8,83 & 5,33 & 4,15\end{array}$




\section{Vymazané položky}

2. Na hodinách chemie nepoužíváme žádné pomůcky.

$$
\begin{array}{rrrr}
0,00 & 0,15 & 0,08 & -0,05 \\
-0,31 & -0,46 & -0,20 & -0,28 \\
0,36 & -0,27 & -0,09 & -0,07 \\
0,13 & -0,08 & -0,02 & -0,17
\end{array}
$$

7. Vědomosti z chemie jsou důležité pro porozumění jiným vyučovacím předmětům. chemie. více soustředit.

$\begin{array}{llll}-0,08 & 0,16 & 0,07 & 0,04\end{array}$

25. Domnívám se, že chemie je jeden z nejlehčích vyučovacích předmětů.

Pozn.: Čísla položek indikují jejich pořadí v dotazníku

\section{$5 \quad$ Výsledky}

Celkové průměrné skóre žáků k chemii bylo 3,27 ( $\mathrm{SD}=0,54)$, což indikuje relativně neutrální postoj. Při detailnějším pohledu je patrné, že žáci vidí význam chemie, jeví o ni zájem a též pozitivně vnímají chemické experimenty (graf na obrázku 1). Jedinou dimenzí, ve které dosáhli žáci negativní skóre, je „Budoucí život a chemie“.

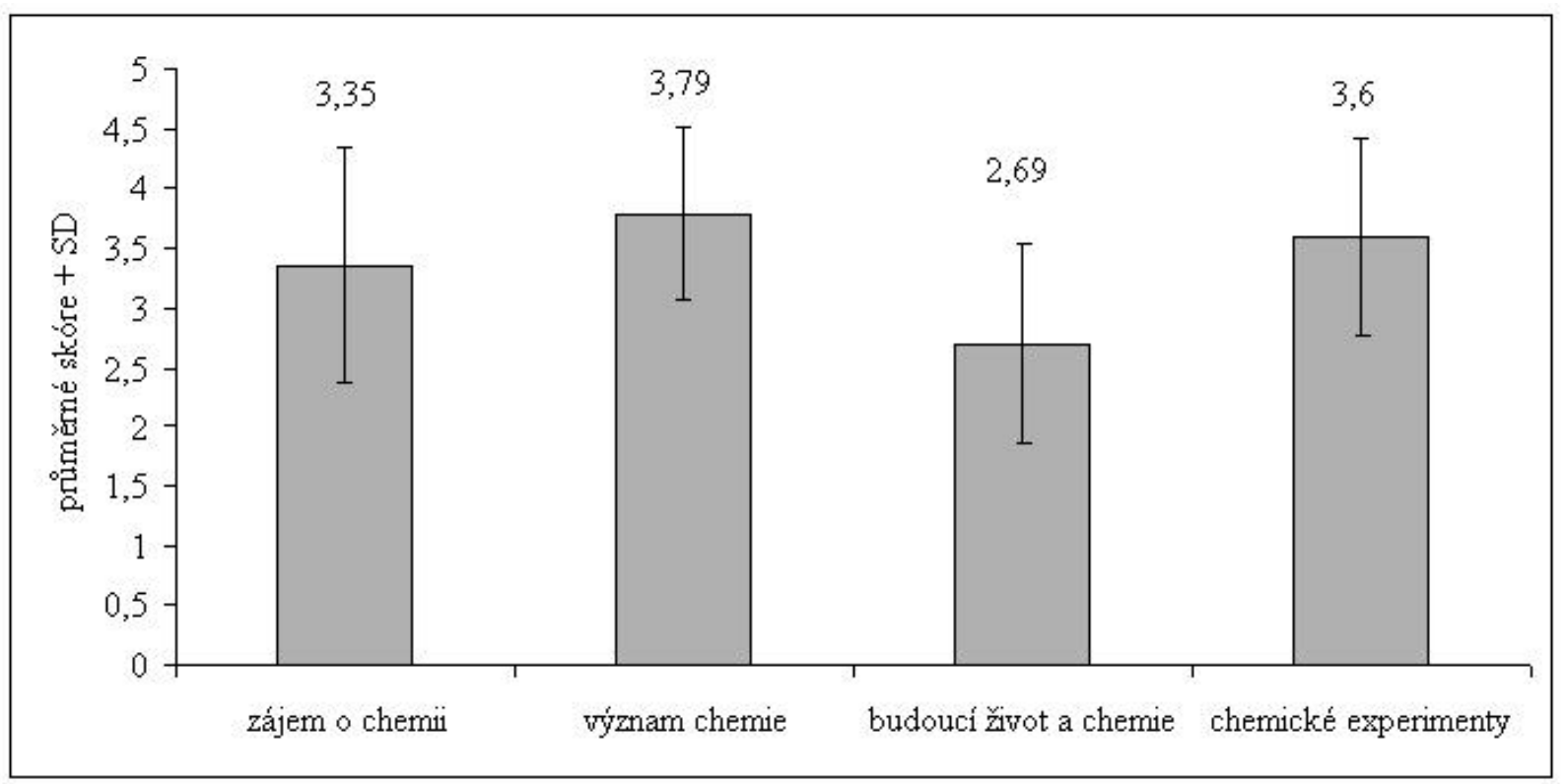

Obrázek 1. Průměrné skóre za jednotlivé dimenze 


\subsection{Vliv oblíbeného předmětu na postoje k chemii}

Při sledování vlivu jednotlivých proměnných byl zjištěn signifikantní rozdíl pouze mezi žáky s oblíbeným př́rodovědným předmětem a žáky s oblíbeným jiným předmětem než př́rodovědným $(\mathrm{t}=4,80, \mathrm{p}<0,001)$, přičemž žáci s oblíbeným přírodovědným předmětem dosahovali vyšší skóre $(x=3,56$; $\mathrm{SD}=0,07) \mathrm{v}$ porovnání se žáky $\mathrm{s}$ oblíbeným jiným než přírodovědným předmětem $(\mathrm{x}=3,21 ; \mathrm{SD}=0,03$; graf na obrázku 2$)$. Rozdíl mezi oběma skupinami je možné pozorovat i v jednotlivých položkách. U položky „Chemii mám raději než ostatní předměty" více než polovina respondentů s oblíbeným př́rodovědným předmětem vyjádřila souhlasné stanovisko, u druhé skupiny to bylo pouze pětina respondentů. Hodiny chemie nepovažují za náročné téměř $2 / 3$ žáků $s$ oblíbeným prrírodovědným předmětem $v$ porovnání se 40 \% žáků s jiným oblíbeným předmětem než je př́rodovědný, pro které není chemie náročná. Nejvýraznější rozdíl mezi těmito dvěma skupinami byl zjištěn u položky „Hodiny chemie bych chtěl/a mít častěji“, kde téměř polovina respondentů vyjádřila souhlasné stanovisko s uvedeným výrokem. Ze žáků $\mathrm{s}$ jiným oblíbeným předmětem než př́rodovědným to bylo pouze necelých $20 \%$. V hodinách chemie se nenudí téměř $3 / 4$ respondentů s oblíbeným př́rodovědným předmětem, ale téměř třetina žáků s jiným oblíbeným předmětem než prŕrodovědným se $\mathrm{v}$ hodinách chemie nudí. Přribližně $70 \%$ respondentů s oblíbeným př́rodovědný předmětem považuje chemii za důležitou v porovnání s 50 \% žáků s jiným oblíbeným předmětem. Zajímavě vyznívá porovnání položky týkající se porozumění chemickému učiva, kdy se 60 \% žáků s oblíbeným prŕrodovědným předmětem musí více soustředit, aby porozumělo chemickému učivu. $Z$ druhé skupiny to bylo přibližně $70 \%$. Procentuální skóre zejména u žáků s oblíbeným přírodovědným předmětem signalizuje vyšší náročnost chemického učiva. Třetina žáků s oblíbeným přírodovědným předmětem je rozhodnuta po ukončení studia pracovat v oblasti př́rodních věd. Tuto možnost si připouští pouze $10 \%$ respondentů s oblíbeným jiným předmětem než přírodovědným. V ostatních položkách byl rozdíl minimální. Hypotéza o vlivu oblíbeného ročníku se akceptuje, protože žáci s oblíbeným př́rodovědným předmětem dosahovali pozitivnější postoj k tomuto předmětu v porovnání se žáky, kteří mají oblíbený předmět jiný než prŕrodovědný. 


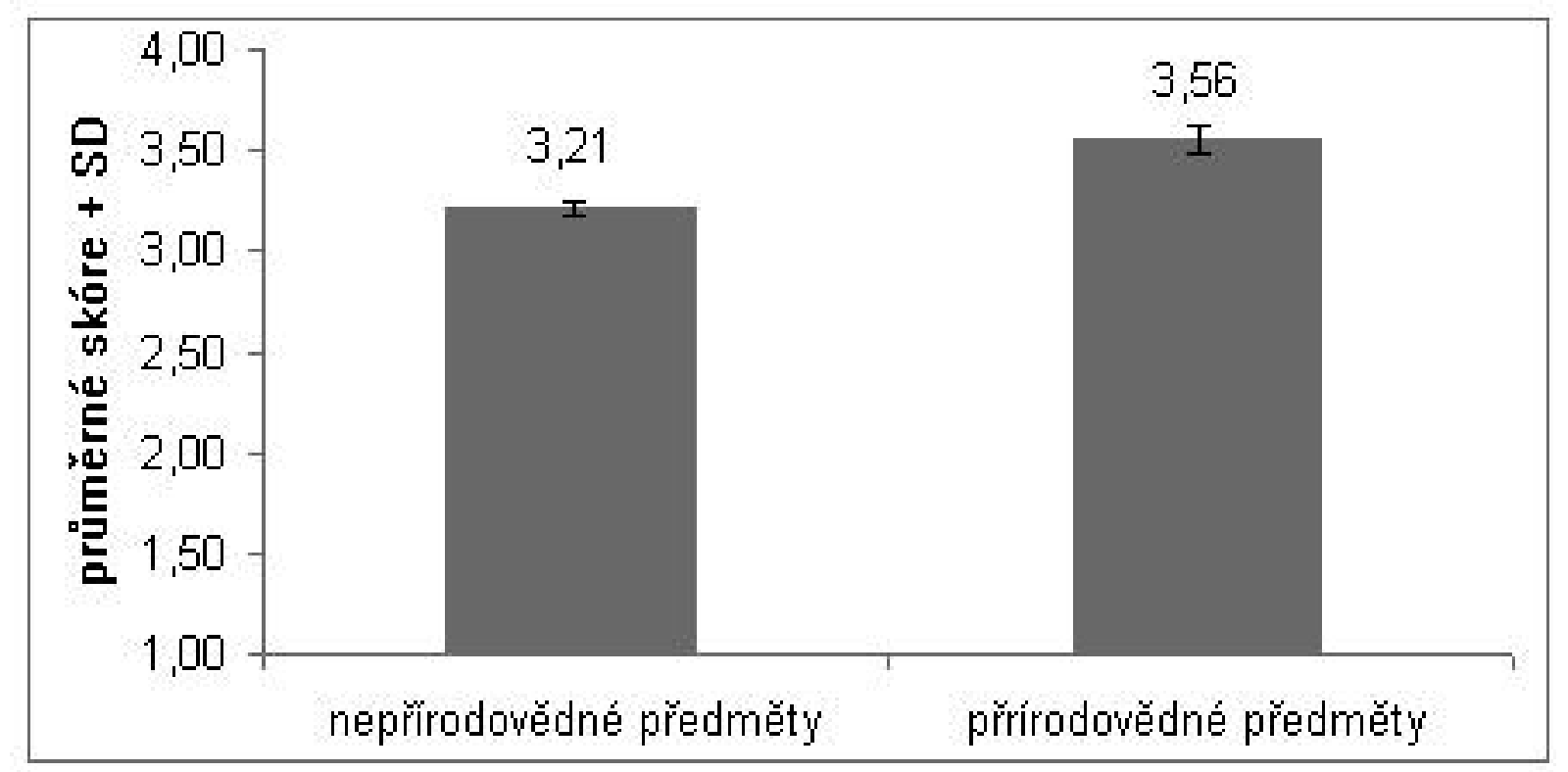

Obrázek 2. Průměrné skóre žáků s ohledem na oblíbený předmět

\subsection{Vliv genderu na postoje $k$ chemii}

Vliv genderu na postoje žáků $k$ chemii byl nevýznamný $(t=1,16 ; p=0,25)$. Při detailnějším pohledu lze pozorovat, že mezi chlapci a dívkami byl rozdíl ve skóre ve prospěch dívek $(\mathrm{x}=3,29 ; \mathrm{SD}=0,56)$ v porovnání $\mathrm{s}$ chlapci $(\mathrm{x}=3,23$; $\mathrm{SD}=0,51)$. Při analýze položek byl určitý rozdíl zjištěn pouze u dvou položek (položky číslo 3 a 22). Pro 60 \% chlapců není chemie a příroda cizí, podobný názor sdílí $70 \%$ dívek. Zajímavý výsledek vzešel z vyhodnocení položky týkající se používání chemických pomůcek, kdy podle poloviny dívek se v hodinách chemie používá hodně chemických pomůcek, přičemž toto tvrzení sdílí necelých 40 \% chlapců. Při vyhodnocování ostatních položek byl rozdíl mezi chlapci a dívkami již minimální. Hypotéza o vlivu genderu se zamítá, protože nebyl zjištěn statisticky významný rozdíl $\mathrm{v}$ postojích $\mathrm{k}$ chemii ve prospěch chlapců.

\subsection{Vliv ročníku na postoje $k$ chemii}

Vliv navštěvovaného ročníku byl nevýznamný $(t=0,02 ; p=0,99)$. Hodnota skóre v obou ročnících byla téměř identická: žáci osmého ročníku dosáhli skóre 3,27 ( $\mathrm{SD}=0,53$ ) a žáci devátého ročníku 3,27 (SD =0,56). Při položkové analýze byl zjištěn rozdíl ve třech položkách (položky číslo 7, 15 
a 20). Přibližně polovina žáků osmého ročníku považuje vědomosti z chemie za důležité pro porozumění jiným předmětům, zatímco toto stanovisko sdílí pouze třetina žáků ročníku devátého. Méně než pětina respondentů z osmého ročníku považuje chemii za stejně důležitou jako ostatní předměty, ale až čtvrtina žáků devátého ročníku považuje chemii za stejně důležitou jako ostatní předměty. Přibližně $20 \%$ žáků z osmého ročníku má rádo hodiny chemie a přibližně o 10 \% více žákủ devátého ročníku má stejný názor. Při vyhodnocování ostatních položek již byl zjištěn minimální rozdíl mezi žáky z osmého a devátého ročníku. Hypotéza týkající se ročníku se zamítá, protože žáci obou ročníků dosahovali téměř identické celkové skóre.

\section{Diskuse a závěr}

Prezentovaná výzkumná studie byla zaměřena na vnímání chemie jako vyučovacího předmětu žáky druhého stupně českých základních škol. Jako výzkumný nástroj byl použit dotazník s 5-stupňovými škálovanými položkami, který lze po určitých úpravách použít i na zkoumání postojů $\mathrm{k}$ jiným předmětům než chemie, přičemž se nemusí jednat pouze o př́rodovědné předměty (biologie, fyzika, zeměpis). Výzkumný nástroj zle použít i na zkoumáníjiné věkové skupiny respondentů, například na středních či vysokých školách. Záměrem autorů bylo také přispět k nevelkému počtu výzkumných prací, které by se zabývaly obdobným tématem.

Celkově byl zjištěn neutrální postoj žáků k chemii, což může být způsobeno vyučovacím obsahem předmětu. Tematické celky se probírají v rychlém sledu za sebou a jejich obsahová náplň je různorodá, proto kvůli krátkému časovému působení nemusí dojít k pozitivnímu či negativnímu vyhranění $\mathrm{k}$ uvedenému předmětu.

První stanovená hypotéza se zamítá, protože nebyl zjištěn statisticky významný rozdíl $\mathrm{v}$ postojích $\mathrm{k}$ chemii ve prospěch chlapců. Výsledku předkládané studie se nejvíc přibližuje zjištění Shannon et al. (1982), kteří uvádějí pozitivnější vnímaní chemie u děvčat v porovnání s chlapci. Druhá hypotéza se také zamítá. Žáci obou ročníků dosahovali identického celkového skóre a také rozdíl $v$ jednotlivých dimenzích byl zanedbatelný. Tím se nepotvrdil předpoklad, který byl vytvořen na základě jiných výzkumných šetření (Menis, 1983), deklarující nárůst pozitivního vnímání chemie s věkem žáků. Důvodem podobnosti výsledků může být charakter učiva, jak již bylo uvedeno, ale též samotný přístup učitele a styl jeho výuky. Většinou vyučuje 
v obou ročnících jeden učitel a probírané učivo prezentuje stejnou formou, stylem, za využití stejných vyučovacích metod a pomůcek. To může mít také vliv na utváření postojů, a možná proto je vnímání chemie v obou ročnících na přibližně stejné úrovni.

Poslední hypotéza se nezamítá, protože žáci s oblíbeným př́rodovědným předmětem dosahovali pozitivnější postoj $\mathrm{k}$ tomuto předmětu v porovnání se žáky, kteří mají oblíbený předmět jiný než př́rodovědný. Stanovenou hypotézu potvrzuje i studie Salta a Tzougraki (2004), kteří však zkoumali zaměření studia na utváření postojů. U studentů, kteří měli studium zaměřené na oblast chemie, byla úroveň postojů pozitivnější než u ostatních. Podobná zjištění uvádějí i Prokop a Komorníková (2007), zabývající se postoji k předmětu přírodopis, kdy u žáků s oblíbeným předmětem přírodopis byl zjištěn významně pozitivnější postoj $\mathrm{k}$ danému předmětu než u žáků s jiným oblíbeným předmětem než př́rodovědným. Daná hypotéza a její potvrzení může vyznívat banálně, ale při detailnějším pohledu na výsledky vidíme, že i žáci s jiným oblíbeným předmětem než je chemie, k ní mají pozitivní postoj.

Studií, které uvádějí, jak změnit postoje žáků k lepšímu, není mnoho, proto jsou níže uvedeny některá z možných doporučení, které mohou zlepšit postoje žáků $\mathrm{k}$ chemii. Jedno z možných doporučení směřuje k vyzdvihnutí důležitosti vzdělávání v oblasti chemie. Žáci možná odmítají se dále věnovat chemii, protože je pro ně př́liš abstraktním předmětem a nedovedou si představit své působení v této oblasti; měli by si však dokázat spojit získané poznatky z chemie se svým každodenním životem (používání čisticích prostředků, automobilismus, kosmetika apod.). Jedním z postupů pro vyučování chemie, na kterém je možnost rozvíjet postoje $\mathrm{v}$ pozitivním směru je aplikace chemických experimentů, laboratorních cvičení a chemických pomůcek, což může $\mathrm{v}$ pozitivní míře formovat utváření postojů díky aktivnímu zapojení žáků do výuky. Vliv chemických experimentů na pozitivní utváření postojů potvrzuje i studie od autorů Wolf a Fraser (2008). Dále je možné aplikovat do výuky chemie i metody neformálního vzdělávání. Nosnými edukačními metodami jsou pozorování a experiment, přičemž se žáci učí vědeckým postupům, pozorování jevům, analyzování a plánování různých experimentů. Při neformálním vzdělávání se uplatní zejména prvky kooperativního a problémového vyučování. Aplikaci neformálního vzdělávání podporuje i Salmi (2003), podle kterého má neformální vzdělávání vliv na zvýšení vnitřní motivace k přírodovědným předmětům. 
Výzkumné šetření se snaží alespoň částečně vyplnit mezeru týkající se zkoumání postojů $\mathrm{k}$ chemii. Ve většině výzkumních prací jsou respondenty studenti středních škol, v naší studii jsou však respondenty žáci základních škol. Dále je zde nabídnut pohled na celkové vnímání chemie, což je poměrně ojedinělé. Většina prací je totiž zaměřena na zkoumání vybraných aspektů vyučovacího předmětu chemie. Kromě zkoumání vlivu genderu na postoje jsou ve studii prezentovány i vliv ročníku a oblíbeného předmětu.

Výzkum v této oblasti by se mohl dále ubírat zjištěním vlivu dalších faktorů, jako je například osobnost učitele či probírané učivo. Také je možné rozšířit výzkumné šetření mezi žáky a studenty středních a vysokých škol.

\section{Literatura}

Dhindsa, H. S., \& Chung, G. (1999). Motivation, anxiety, enjoyment and values associated with chemistry learning among form 5 Bruneian students. Paper presented at the MERA-ERA Joint Conference, Malacca, Malaysia.

Glasman, L. R., \& Albarracín, D. (2006). Forming attitudes that predict future behaviour: a meta-analysis of the attitude-behaviour relation. Psychological Bulletin, 132(5), 778-822.

Harvey, T. J., \& Stables, A. (1986). Gender differences in attitudes to science for third year pupils: An argument for single-sex teaching groups in mixed schools. Research in Science and Technological Education, 4(2), 163-170.

Kelly, A. (1988). The customer is always right: Girls' and boys' reactions to science lessons. School Science Review, 69(249), 662-676.

Menis, J. (1983). Attitudes towards chemistry as compared with those towards mathematics, among tenth grade pupils (aged 15) in high level secondary schools in Israel. Research in Science \& Technological Education, 1(2), 185-191.

Morrell, P. D., \& Lederman, N. G. (1998). Students' Attitudes Toward School and Classroom Science: Are They Independent Phenomena? School Science and Mathematics, 98(2), 76-83.

Oskamp, S., \& Schultz, P. W. (2005). Attitudes and opinions (3rd ed.). Mahwah, NJ: Lawrence Erlbaum Associates.

Pavelková, I., Škaloudová, A., \& Hrabal, V. (2010). Analýza vyučovacích předmětů na základě výpovědí žákủ. Pedagogika, 60(1), 38-61.

Prokop, P., \& Komorníková, M. (2007). Postoje k prírodopisu u žiakov druhého stupňa základných škôl. Pedagogika, 57(1), 37-46.

Salmi, H. (2003). Science centers as leasing laboratories: Experience of Heureka, the Finnish Science Centre. International Journal of Technology Management, 25(5), 460-476.

Salta, K., \& Tzougraki, C. (2004). Attitudes toward chemistry among 11th grade students in high schools in Greece. Science Education, 88(4), 535-547.

Shannon, A. G., Sleet, R. J., \& Stern, W. (1982). School students' attitudes to science subjects. Australian Science Teachers Journal, 28(1), 77-82. 
Sjøberg, S., \& Schreiner, C. (2010). The ROSE project. An overview and key findings. Dostupné zhttp://roseproject.no./network/countries/norway/eng/nor-Sjoberg-Schreiner-overview2010.pdf.

Veselský, M., \& Hausnerová, R. (2010). Motivácia žiakov učit’ sa prírodopis - biológiu na základnej škole. Technológia vzdelávania, 18(8), 11-15.

Veselský, M., \& Hrubišková, H. (2009). Zájem žáků o učební předmět chemie. Pedagogická orientace, 19(3), 45-64.

Weinburgh, M. (1995). Gender differences in student attitudes toward science: A meta-analysis of the literature from 1970 to 1991. Journal of Research in Science Teaching, 32(4), 387-398.

Wolf, S. J., \& Fraser, B. J. (2008). Learning environment, attitudes and achievement among middle-school science students using inquiry-based laboratory activities. Research in Science Education, 38(3), 321-341.

\section{Autoři}

PaedDr. Milan Kubiatko, PhD., Masarykova univerzita, Pedagogická fakulta, Institut výzkumu školního vzdělávání, Poříčí 31, 60300 Brno, e-mail: mkubiatko@gmail.com

Mgr. Kateřina Švandová, Masarykova univerzita, Pedagogická fakulta, Institut výzkumu školního vzdělávání, Poříčí 31, 60300 Brno, e-mail: katkasvandova@gmail.com

Mgr. Jiří Šibor, Ph.D., Masarykova univerzita, Pedagogická fakulta, Katedra chemie, Poříčí 7, 60300 Brno, e-mail: sibor@ped.muni.cz

Doc. PhDr. Jiř́ Škoda, Ph.D., Univerzita Jana Evangelisty Purkyně, Pedagogická fakulta, Katedra pedagogiky, České mládeže 8, 40096 Ústí nad Labem, e-mail: Jiri.Skoda@ujep.cz

\section{Lower secondary school pupils' perception of chemistry}

Abstract: There are a small number of research studies investigating lower secondary school pupils' attitudes toward chemistry. Existing studies focus mainly on the influence of gender on the attitudes toward chemistry. In this paper we present an investigation of the influence of gender, grade and, class and favourite subject and also an overall index of attitudes toward chemistry. The sample consisted of 379 pupils from eight lower secondary schools. The number of boys and girls was approximately similar; there were more pupils from the $8^{\text {th }}$ grade and 102 pupils with chemistry as favourite subject. The measurement tool was a questionnaire with 25 Likert type 
items. After applying factor analysis, the items were distributed into four dimensions: The interest in chemistry, The relevance of chemistry, The future life and chemistry and The chemical experiments. The independent two-sample t-test was used for determining the differences among groups of categorical variables. A significant difference was found only in the dimension favourite subject. Pupils with chemistry as favourite subject achieved more positive attitudes. Girls achieved higher score in comparison with boys. The pupils from both grades achieved almost similar scores. Possibilities of further investigations are suggested in the conclusion.

Keywords: attitudes toward chemistry, questionnaire with scale items, Czech lower secondary school pupils

\section{Studia paedagogica 2/2011}

Druhé loňské číslo časopisu Studia paedagogica přináší tyto stati: Škola jako téma rozhovorů mezi dětmi a rodiči (I. Smetáčková), Mimořádné události v komunikaci rodiny a školy (I. Viktorová), Paleta hodnoticích situací a hodnoticích přístupů ve výtvarné výchově (K. Brücknerová), Bez prírodopisu to nejde alebo Ako ho vnímajú žiaci základných škôl (M. Kubiatko), Spätná väzba ako faktor ovplyvňujúci lingvistickú a komunikatívnu úroveň produktívnej zručnosti písania (D. Sršníková), Evaluace jako diskurz. Komunikace a/versus kontrola v novém modelu školní inspekce v Polsku (G. Mazurkiewicz, B. Walczak), Hodnoty v prostředí punkové subkultury (K. Lojdová). Vedle toho zaujme rozhovor se Stephenem J. Ballem: Pokus o teorii nepořádku a také dvě studentské práce: Role rodičů v domácí přípravě do školy (R. Pospíšilová), Profesní start absolventek studijního oboru sociální pedagogika a poradenství (M. Kánská).

http://www.phil.muni.cz/journals/index.php/studia-paedagogica/issue/current

\section{Hrbáčková, K. \& kol. (2010). Kognitivní a nonkognitivní determinanty rozvoje autoregulace učení studentů. Brno: Paido.}

Kolektivní monografie složená ze sedmi studií se věnuje fenoménu autoregulace, který se v současnosti stává jednou z klíčových psychologických i pedagogických kategorií. První část publikace rozdělená do dvou kapitol objasňuje základní pojmy z oblasti autoregulace učení. Druhá část publikace prezentuje výsledky výzkumu vycházejícího z empirického ověření Dotazníku autoregulace učení studentů. Třetí část monografie poukazuje na některé přesahy autoregulace učení směrem k duchovnímu růstu jedince nebo interkulturnímu učení. 